\title{
The Impact of the Humate Nature Feed Additives on the Antioxidative Status of Erythrocytes, Liver, and Muscle in Chickens, Hens, and Gerbills
}

\author{
Lilia Stepchenko $^{1(\mathbb{D})}$, Olga Dyomshyna ${ }^{2, *} \mathbb{D}$, Galyna Ushakova ${ }^{2(\mathbb{D})}$ \\ 1 Dnipro State Agrarian-Economic University, 25 Sergey Efremov str., Dnipro 49027, Ukraine; stepchenko2@ gmail.com \\ (L.M.); \\ 2 Oles Honchar Dnipro National University, 72 Gagarin Ave., Dnipro 49010, Ukraine; d.olga.1970@ gmail.com (O.D.); \\ ushakova_g@ukr.net (G.U.); \\ * Correspondence: d.olga.1970@gmail.com; (G.U.);
}

Scopus Author ID 7004018560

Received: 7.01.2021; Revised: 2.02.2021; Accepted: 4.02.2021; Published: 8.02.2021

\begin{abstract}
Our study's goal was to determine the oxidation states of formed elements of the blood, and mitochondria of liver and muscles of chicken and gerbils could help establish and compare the humic substance's impact. The experiment was carried out on hens of the Lohmann Braun, chicken-broilers of the Cobb 500 cross, and 6-months-old gerbils, which were kept under standard conditions. Experimental hens, chicken-broilers, and gerbils were divided into 2 groups: 1 - intact animals (control), 2 - animals, which added to the drinking water a $1 \%$ solution of the fodder biologically active additive of humic nature (Humilid or Hydrohumate) in the optimal amount for 21 days. Results showed that Humilid and Hydrohumate tested in our experiment activated the protective systems in cells against toxic radicals. The species-specific effects of the components of studied humates were established: the activation of the glutathione blood protection system of hens; catalase activation in mitochondria of white muscles of chicken-broilers; activation of catalase and increase of concentration of cytochrome $\mathrm{C}$ in liver mitochondria of gerbils. Our results indicate the elucidation of the mechanisms of humic.
\end{abstract}

Keywords: humate nature feed additives; blood, tissues; mitochondria; antioxidation systems.

(C) 2021 by the authors. This article is an open-access article distributed under the terms and conditions of the Creative Commons Attribution (CC BY) license (https://creativecommons.org/licenses/by/4.0/).

\section{Introduction}

Implementation of the latest technologies using biologically active additives of humic nature obtained from ecologically safe peat of Ukraine can increase the efficiency of production of high-quality biological products in the agro-industrial sector of the economy [1-2]. It is known that this is possible due to the impact on the metabolic processes of such substances as proteins, carbohydrates, lipids [3-6]. Simultaneously, with an increase in productivity, the redox balance may change [7-11]. Due to the broad interest in the antioxidant properties of humic substances, a comparison of the mechanisms of their effect on poultries and rodents (animals far removed from each other in the systematic evolutionary hierarchy) is an urgent issue in biology, veterinary medicine, ecology, and agriculture [12-15]. The elucidation of such mechanisms and the establishment of interconnections between different living organisms that differ in metabolism and regulation of the antioxidant system make it possible to give recommendations when raising highly productive animals.

Fodder biologically active additives based on humic substances developed and tested by the staff of the research laboratory of humic substances L. A. Christeva, the Dnipro State 
Agrarian, and Economic University: Humilid [16-20]; Hydrohumate [21] demonstrate highly adaptogenic and anti-diabetic, analgesic, immunostimulating and antimicrobial activity. Humates are active in forming a stable chelate compound with trace elements, which positively affects the conversion of feed and promotes the intensification of growth and improvement of farm animals' quality of meat $[12,22]$. The important biological activity of humates is due to effect on hormone status, additional synthesis of adenosine triphosphate (ATP), deoxyribonucleic acid (DNA), ribonucleic acid (RNA), change the cyclic adenosine monophosphate (cAMP) level, and activation of the biosynthesis of proteins [22]. As a rule, for increasing the productivity of farm animals requires a significant of nutrients in the feed. Scientists [22-24] have shown that when humic substances are added to animals' diet, the absorption of nutrients increases due to the activation of digestive enzymes in all digestive canal locations.

There is a generally accepted concept of antioxidant protection, which includes three defense lines [25]. Antioxidant enzymes belong to the first line: superoxide dismutase, glutathione-peroxidase, catalase, metalloproteins; the second line - low molecular weight antioxidants: glutathione, ascorbic acid, tocopherol, carotenes; the third line includes special DNA repair enzymes, chaperone proteins, sirtuins, phospholipases. Also, apoptosis is the third line of defense - a complex process that starts in the cell with irreversible damage. In experiments on domestic and laboratory animals shows that humic substances cause activation of the system of antioxidant protection of blood and cardiomyocytes, liver, and mitochondria by increasing the activity of superoxide dismutase (SOD) and catalase (CT) [16-20,26-29]. The authors point out that the delivery and retention inside the cell of $\mathrm{Zn}, \mathrm{Cu}, \mathrm{Mn}, \mathrm{Fe}$ included in the active centre of enzymes is facilitated by humic substances that form chelate complexes with macro and microelements [7,16,30,31].

Therefore, the study of the liver and blood levels' biochemical markers and the intensity of the antioxidant system's functioning are relevant and important issues for biochemistry, veterinary and humane medicine, and pharmacology. The search for medicinal products that simultaneously exhibits biological activity and hepatoprotective properties is also an urgent task.

Considering the considerable achievements in the study of the biological activity of humic substances, the purpose of the work was to establish and compare the impact of Humilid on the effectiveness of the state of the antioxidant system of formed elements of the blood, liver, and muscles of chicken and gerbils.

\section{Materials and Methods}

\subsection{Chemicals.}

$1 \%$ solution of the fodder biologically active additive of humic nature (Humilid or Hydrohumate) was used. Chemicals have been obtained from Khristyeva Problem Laboratory of Humic Substances, Dnipro State Agrarian and Economic University (Dnipro, Ukraine). Peat for a feed additive was selected using a screening system its assessment [32]. Humilid was tested for biosafety previously [33]. 


\subsection{Animals and genotyping.}

In the study were experimental animals chicken-broilers (fast-growing chicks) of the Cobb 500 cross, hens of the Lohmann Braun, and 6-months-old gerbils, kept under standard conditions. All manipulation was carried out under the rules of the "European Convention for the Protection of Vertebrate Animals Used for Experimental and Other Scientific Purposes" (Strasbourg, 2010) [34] and Law of Ukraine "On Protection of Animals from Cruel Treatment" (2006) [35].

Experimental hens, chicken-broilers, and gerbils were divided into 2 groups: 1 - intact animals (control), 2 - animals, which added to the drinking water a $1 \%$ solution of the fodder biologically active additive of humic nature (Humilid or Hydrohumate) in the optimal amount [18] for 21 days. At the end of the experiment, after selective weighing, the deposition was performed under anesthesia. Blood, muscle, and liver were collected, washed with saline solution, and used for further studies.

\subsection{Blood.}

Blood collected with an anticoagulant was centrifuged at 1000-1200 rpm for 10-15 minutes; the supernatant was used for further analysis. Whole blood was used to determine the activity of catalase. The concentration of reduced glutathione was determined by [36]. The sulfhydryl group of reduced glutathione reacts with 5,5-dithiobusiness (2-nitrobenzoic acid) (Elman reagent), resulting in a yellow-colored thionitrofenyl anion (THFA), with maximum absorption at $405 \mathrm{~nm}$.

The activity of glutathione peroxidase (GP, EC 1.11.1.9) for changing the glutathione content of the model substrate and color development reaction, glutathione reductase (GR, EC 1.6.4.2) - the speed NADPN•H-dependent conversion of oxidized glutathione form restored to, glutathione-S-transferase (T-S-T, EC 2.5.1.1.8) - the speed of reaction of reduced glutathione with 1-chloro-2,4-dinitrobenzene content of reduced glutathione (GSH) - under the method is based on the interaction of thiol groups by acid-soluble Elman reagent [37] were analyzed in erythrocytes. The activity $\gamma$-glutamyltransferase (GGT, EC 2.3.2.2) was determined with standard laboratory test kits (PZ CORMAY S.A., Lomianki, Poland) according to [38], using the manufacturer's protocol. The activity of enzymes glutathione content in red blood cells was counted per $1 \mathrm{~g}$ of hemoglobin.

Hemoglobin concentration was determined by a well-known method using acetone cyanohydrin and a set of standard reagents (Reagent, Ukraine, Dnipro) according to [39].

\subsection{Homogenate and isolation mitochondria.}

Whole homogenate and mitochondria fraction of liver or musculus were obtained by differential centrifugation in the following buffer medium: $250 \mathrm{mM}$ sucrose, $1 \mathrm{mM}$ ethylenediaminetetraacetic acid (EDTA), $10 \mathrm{mM}$ Tris- $\mathrm{HCl} ; 2 \mathrm{mM} \mathrm{MgCl}_{2} ; \mathrm{pH} 7.4$ at $0-3{ }^{\circ} \mathrm{C}$ [40]. The liver or muscles' homogenate was centrifuged at $740 \mathrm{~g}$ in $10 \mathrm{ml}$ of medium for 5 minutes at $0-2{ }^{\circ} \mathrm{C}$ to remove the cellular fragments and isolate the nuclear fraction. The resulting supernatant was used to determine the biochemical parameters and to obtain the mitochondrial fraction. The supernatant was centrifuged at $740 \mathrm{~g}$ again for 5 minutes at $0-2{ }^{\circ} \mathrm{C}$. For purification of the mitochondria, the supernatant was centrifuged at $9000 \mathrm{~g}$ for $10 \mathrm{~min}$ twice. The supernatant containing the plasma membrane, lysosomes, microsomes, and cytosol were discarded. The collected pellet, including the mitochondria, was resuspended to $10 \mathrm{ml}$ in 
the medium for further centrifugation at $10000 \mathrm{~g}$ for 10 minutes. The pellet containing the mitochondria was suspended in buffer with $0.25 \mathrm{M}$ sucrose-free of EDTA and centrifuged at $10000 \mathrm{~g}$ for $10 \mathrm{~min}$ again. The procedure was repeated twice. The dense sediment of mitochondria was thoroughly suspended in a pipette containing $0.4-0.5 \mathrm{ml}$ of $0.25 \mathrm{M}$ sucrose. The fraction of mitochondria was immediately used for studies.

\subsection{Enzyme assays.}

The total protein concentration was determined due to standard laboratory test kits (PZ CORMAY S.A., Lomianki, Poland) according to [38], using the manufacturer's protocol. The catalase activity (CT, EC 1.11.1.6) was determined by hydrogen peroxide's ability to form a stable colored complex with molybdenum salts [41] and was expressed in $\mu$ cat $/ \mathrm{mg}$ of mitochondrial fraction protein. The activity of superoxide dismutase (SOD, EC 1.15.1.1) was evaluated as the ability of the enzyme to inhibit quercetin oxidation [42] and was expressed in conventional units (c.u./mg of protein). The enzyme activity that was able to induce quercetin inhibition by $50 \%$ per $1 \mathrm{mg}$ tissue protein was taken as a unit. The number of cytochrome $\mathrm{C}$ was measured due to its ability to restore sodium dithionate [43].

\subsection{MDA concentration.}

The concentration of MDA was determined by the concentration of the colored complex formed by the reaction of MDA in an acid medium with two molecules of thiobarbituric acid (TBA) [44]. The amount of MDA was expressed as $\mu$ moles of TBA-active products per $\mathrm{mg}$ of protein of homogenate or mitochondrial fraction.

Data analysis and statistics

Statistical analysis using one-factor analysis of variance ANOVA. For all statistical calculations, the significance was considered as a value of $\mathrm{P}<0.05$. Correlation analysis was performed with Pearson's coefficient.

\section{Results and Discussion}

\subsection{Impact of the Hydrohumat in the red blood cells.}

The data of the prooxidant-antioxidant status of enzymes of the glutathione group in the hens' red blood cells under the effect of Hydrohumate were presented (Table 1). Supplementation of diet of the hens with fodder biologically active additive Hydrohumate led to decrease 1,6 times $(\mathrm{P}<0,001)$ the activity of GP and 2,1 times $(\mathrm{P}<0.001)$ of G-S-T, respectively, in erythrocytes, and increased GR activity 1.9 times $(\mathrm{P}<0.001)$ compared to the corresponding parameters of the control group. The total MDA level in the hens' red blood cells was less than 1.52 times $(\mathrm{P}<0.001)$ than control one.

Table 1. The content of MDA, and the activity of the glutathione cycle enzymes in the red blood cells of the hens under Hydrohumate impact, $\mathrm{M} \pm \mathrm{SD} ; \mathrm{n}=6$.

\begin{tabular}{|c|c|c|c|c|c|}
\hline $\begin{array}{c}\text { Experimental } \\
\text { group }\end{array}$ & $\begin{array}{c}\text { MDA, } \mu \mathrm{mol} / \mathrm{g} \\
\mathrm{Hb}\end{array}$ & $\begin{array}{c}\text { GP, } \\
\mu \mathrm{mol} / /(\mathbf{m} \cdot \mathbf{g H b})\end{array}$ & $\begin{array}{c}\text { GR, } \\
\mu \mathrm{mol} / /(\mathbf{m} \cdot \mathbf{g H b})\end{array}$ & $\begin{array}{c}\text { G-S-T, } \\
\mu \mathrm{mol} / /(\mathrm{m} \cdot \mathrm{g} \mathrm{Hb})\end{array}$ & $\begin{array}{c}\text { GGT, } \\
\mu \mathrm{mol} / /(\mathbf{m} \cdot \mathbf{g H b})\end{array}$ \\
\hline Control & $0,38 \pm 0,02$ & $859,42 \pm 26,99$ & $3,18 \pm 0,13$ & $10,95 \pm 0,28$ & $70,8 \pm 1,58$ \\
\hline Hydrohumate & $0,25 \pm 0,01 *$ & $528,40 \pm 36,82 * *$ & $6,05 \pm 0,26^{* *}$ & $5,24 \pm 0,39 * *$ & $47,4 \pm 0,87 * *$ \\
\hline
\end{tabular}

The changes in the content of various forms of glutathione in hens' blood were showed (Table 2). The diet with Hydrogumat led to an increase of 1,3 times $(\mathrm{P}<0.001)$ the 
concentration of GSH and decreased the GSSG in the same times, to increase 1.8 times (P $<0.001)$ the ratio GSH/GSSG in erythrocytes of blood hens compared to the control group. These data are correlated with changes in enzyme activity of the glutathione group.

Table 2. The content of various forms of glutathione in the blood of hens, $M \pm S D, n=6$.

\begin{tabular}{l|c|c|c|c}
\multirow{2}{*}{ Experimental group } & \multicolumn{3}{|c|}{ Glutathione, mg\% } & \multirow{2}{*}{ GSH/GSSG } \\
\cline { 2 - 4 } & Total & GSH & GSSG & \\
\hline Control & $96,82 \pm 1,94$ & $76,22 \pm 2,07$ & $20,61 \pm 0,90$ & $3,74 \pm 0,24$ \\
\hline Hydrohumate & $114,65 \pm 1,27^{* *}$ & $99,40 \pm 1,13^{* *}$ & $15,25 \pm 0,98^{*}$ & $6,64 \pm 0,45^{* *}$
\end{tabular}

Supplementation to the diet to hens of the Lohmann Braun the fodder biologically active additive Hydrohumate led to decreased glutathione peroxidase activity and glutathione-Stransferase, and increased glutathione reductase activity in erythrocytes compared to the control group. A high level of GP activity against high content of reduced glutathione in red blood cells of control hens compared to poultry of experimental groups (Table 1) indicates intensive neutralization of products of lipid peroxidation (LPO), which is a substrate for GP. Usually, the oxidative product excessive formated naturally in old cells [16].

The decrease of GP activity on the background of low GSH content in the red blood cells of hens of experimental groups is probably due to the low content of LPO metabolites, resulting from a decrease in the intensity of these processes the cells under the impact of humic compounds. Such activity of the GP can be considered an improvement of red blood cells' functional state due to their renewal with red bone marrow participation. This fact is also confirmed by decreasing G-S-T activity in the hens of experimental groups' red blood cells. The substrate for this enzyme is endogenous toxins and low-oxidized products. In this case, the potentially high activity of GR relative to the control index may be due to the presence of a substrate - GSSG formed in cells due to the detoxification of LPO products involving GSH, and is aimed at maintaining a high ratio GSH/GSSG (Table 2). A significant predominance of this indicator in the blood of the hens of experimental groups over the control index, in particular by $77.5 \%(\mathrm{P}<0.001)$ with Hydrohumate application, is evidence of a proper oxidative-reducing state of erythrocytes, that is due to the impact of humic substances on the system of their antioxidant protection. Besides, GR takes part in the restoration of disulfide bonds of proteins, reflected in membranes' permeability and oxidative phosphorylation processes [16]. Unlike experimental poultry, in the red blood cells of the control group, the decrease in the activity of GH can indicate a possible decline in the level of antioxidant protection of these cells, which is due to the intensification of the processes of LPO, whose metabolites have a negative effect on the structure of the cell membrane, and also reduce the activity of functional proteins of red blood cells due to blocking their disulfide bonds. The content of MDA in the red blood cells of the laying hens by the effect of the studied feed biologically active additives was more than 1.5 times $(\mathrm{P}<0.001)$ less than that in the control hens (Table 1), indicating low-intensity processes of LPO in erythrocytes of experimental poultry and is positively reflected on the structure of cell membranes. The confirmation of this is the manifestation of a positive correlative connection $(r=0,59 \ldots 0,81)$ between the content of MDA and the level of activity of GR, GP, or G-S-T in erythrocytes of the hens with a diet supplemented by humic fodder.

The level of GGT activity, as the key enzyme for glutathione metabolism, in the hens' blood serum was significantly lower than the benchmark of $35.4 \%(\mathrm{P}<0.001)$ due to the influence of the Hydrohumate. The high level of GGT activity in the blood serum of the hens in the control group can be attributed to the development of destructive processes in the poultry 
organism, in particular the damage of membranes of cells of the biliary ducts of liver and ducts of the pancreas, of renal tubule system, that is associated with activation of the LPO in the cells. The low level of GGT activity in the blood serum of hens of experimental groups indicates that the studied feed additives stabilize the structure of the membranes of the internal organs' cells. The obtained results are consistent with the previous data [45].

Consequently, the humic substances of the fodder biologically active additive Hydrohumate affect the functional state of erythrocytes. Improve metabolic reactions and antioxidant defense systems by speeding up red cell renewal. Such changes prevent the development of oxidative and hypoxic stress in the organism of productive poultry and positively reflect its physiological status.

\subsection{Impact of Humilid in the liver and muscles of gerbils and chicken-broilers.}

The formation of MDA is a marker of oxidative stress in cells. The diet supplemented with $1 \%$ Humilid in drinking water has not changed the concentration of MDA in the homogenate of gerbil's and chicken broilers liver significantly, as in muscles of chickenbroilers too (Table 3). CT's activity in the homogenate of the liver of gerbils under impact of Humilid was increased 1.7 times, but the activity of SOD, in this case, varied within the control group. In the liver of chicken-broilers, the activity of SOD decreased 1.6 times. However, the activity of CT varied within the control group. The concentration of cytochrome $\mathrm{C}$ increased 1.3 times in the liver of gerbils under Humilid effect. At that time, it was not changed in the liver and muscles of chicken-broilers.

Humic substances with food are digested in the gastrointestinal tract $70 \%$ on average [46]. With blood flow, first of all, on the gate system, get to the liver. Biotransformation of humic substances occurs mainly in the liver [22]; those metabolites cause biological effects.

Table 3. The content of MDA, cytochrome C, and catalase and superoxide dismutase activity in the homogenate of liver chicken-broilers and gerbils, $\mathrm{M} \pm \mathrm{SD}, \mathrm{n}=6$.

\begin{tabular}{l|l|l|l|l}
\multirow{2}{*}{ Experimental group } & \multicolumn{4}{c}{ Parameters } \\
\cline { 2 - 4 } & $\begin{array}{l}\text { MDA, } \mu \text { mol per mg } \\
\text { of protein }\end{array}$ & $\begin{array}{l}\text { Catalase, } \mu \text { kat per mg } \\
\text { of protein }\end{array}$ & $\begin{array}{l}\text { SOD, c.u. per mg of } \\
\text { protein }\end{array}$ & $\begin{array}{l}\text { Cyt C, } \mu \text { mol per g of } \\
\text { tissue }\end{array}$ \\
\hline \multicolumn{5}{|c|}{ Liver of chicken-broilers } \\
\hline Control & $2.97 \pm 0.17$ & $0.16 \pm 0.01$ & $0.14 \pm 0.002$ & $18.40 \pm 0.10$ \\
\hline Humilid & $2.63 \pm 0.11$ & $0.17 \pm 0.01$ & $0.09 \pm 0.02^{*}$ & $18.46 \pm 0.38$ \\
\hline \multicolumn{5}{|l|}{ Liver of gerbils } \\
\hline Control & $3.07 \pm 0.23$ & $6.16 \pm 1.24$ & $6.79 \pm 0.90$ & $2.79 \pm 0.10$ \\
\hline Humilid & $2.77 \pm 0.46$ & $10.30 \pm 1.82^{*}$ & $7.09 \pm 0.76$ & $3.56 \pm 0.28^{*}$
\end{tabular}

A high metabolic load in fast-growing farm animals can cause a decrease in the functionality of the liver. This state caused the formation of oxidative stress. Free radicals increase intracellular calcium overloading, suppression of energy production, decreased protein synthesis, and increased proteolysis. In general, there is a decline in the health status, productivity, and quality of animal products [47-50]. However, normally in cells, the level of biological radicals is maintained at an optimal level due to a complex antioxidant protection system that includes high molecular weight components and low molecular weight [51,52]. These bio-antioxidants inactivate the physiological concentrations of free radicals to the manifestation of their damage to biomolecules.

The first reaction of the cell to xenobiotics in the formation of active forms of oxygen, including MDA, increasing the number of that is one of the markers of oxidative stress in the cell (Table 3). The diet supplemented with $1 \%$ Humilid has not changed the concentration of 
MDA in the homogenate of gerbels and chicken-broilers liver and chicken-broilers' muscles significantly.

Obtained data showed that the mechanism of modulation of catalase activity and SOD of the liver of rodents and poultry under Humilid impact is different. CT's activity was increased in the homogenate of the liver of gerbils with diet supported with Humilid, but the activity of SOD, in this case, varied within the control group. In the liver of chicken-broilers of the Cobb 500 cross, the activity of SOD was decreased; the activity of CT varied within the control group. There is an activation CT in the liver rodent and inhibition SOD in the liver of poultry. The biologically active components of Humilid may affect the liver due to activation of adaptation processes, as noted earlier [45,53]. Possible decrease in the activity SOD connected with antioxidant properties humic substances in compound Humilid. As a result, there is a decrease in the concentration of oxidized products, including superoxide anion.

One possible way to activate the enzymatic activity of the antioxidant system is to increase the concentration of metals in the liver, which are part of the active centers of metal proteins: $\mathrm{Zn}$ - catalase, $\mathrm{Mn}(\mathrm{Cu} / \mathrm{Zn})$ - superoxide dismutase [54].

Chelating compounds based on humic substances ensure the continuous use of trace elements for the synthesis of metalloproteins. Besides, it is known that the humic acids directly exhibits antioxidant or antiradical activity. Through direct interaction, it can neutralize various forms of active oxygen and other free radicals that are formed during the metabolism [30, 55]. Such an effect may be mediated through signal transduction through the adenylate cyclase hormonal system [22].

The effect of Humilid on the concentration of cytochrome $\mathrm{C}$ in the liver and muscles of gerbils and chicken-broilers, changes detected only for the liver of gerbils (Table 3). One of the mechanisms for increasing the cytochrome $\mathrm{C}$ concentration in the cytosol is the activation of oxidative processes in the cell. Changes in the redox status in the cytosol lead to activation of lipid oxidation, especially in the membranes' composition. Markers of such oxidative processes are MDA. In the group of animals to which Humilide was added, the concentration of MDA varied within the control group (Table 3). This indicates the absence of the development of oxidative stress in the liver of this studied group's gerbils. Thus, an increase in cytochrome $\mathrm{C}$ concentration can be explained by the stimulation of synthetic processes in the liver gerbils' cells with humic acids in the composition of Humilid. This confirms the regulatory properties of humic acids shown in the works of Stepchenko (2010) [22]. The obtained data coincide with the work of other researchers $[17,27,56]$. Besides, Humilid can be a source of ions Ferrum to synthesize heme, which is part of cytochrome $\mathrm{C}$.

\subsection{Impact of Humilid in mitochondria of muscles of chicken-broilers and liver of gerbils.}

The oxidized products decreased 1,5 times in the mitochondria of chicken-broilers' muscle under Humilid impact compared to the control group (Table 4). Simultaneously, CT's activity increased 1.42 times, and the activity of SOD decreased 1.45 times compared to the control group. The cytochrome $\mathrm{C}$ concentration was not changed significantly as in homogenate and mitochondria of muscles chicken-broilers under Humilid impact.

At the same conditions, a decrease of 2 times the number of MDA was determined in the mitochondria of liver gerbils relative to the control group under the Humilid effect (Table $5)$. 
Table 4. The content of MDA, cytochrome $C$, and catalase and superoxide dismutase activity in the homogenate and mitochondria of chicken-broilers muscles, $\mathrm{M} \pm \mathrm{SD}, \mathrm{n}=6$.

\begin{tabular}{l|l|l|l|l}
\multirow{2}{*}{ Experimental group } & \multicolumn{4}{c}{ Parameters } \\
\cline { 2 - 5 } & $\begin{array}{l}\text { MDA, } \mu \text { mol per } \mathrm{mg} \\
\text { of protein }\end{array}$ & $\begin{array}{l}\text { Catalase, } \mu \text { kat per } \\
\text { mg of protein }\end{array}$ & $\begin{array}{l}\text { SOD, c.u. per mg of } \\
\text { protein }\end{array}$ & $\begin{array}{l}\text { Cyt C, nmol per g of } \\
\text { tissue }\end{array}$ \\
\hline \multicolumn{5}{|c}{ Muscles of chicken-broilers } \\
\hline Control & $6.29 \pm 0.79$ & $0.24 \pm 0.09$ & $0.48 \pm 0.09$ & $16.37 \pm 0.24$ \\
\hline Humilid & $6.02 \pm 0.03$ & $0.30 \pm 0.03$ & $0.42 \pm 0.11$ & $15.85 \pm 1.19$ \\
\hline \multicolumn{5}{|l}{ Mitochondria of muscles } \\
\hline Control & $0.76 \pm 0.17$ & $0.19 \pm 0.01$ & $1.84 \pm 0.35$ & $33.01 \pm 2.95$ \\
\hline Humilid & $0.51 \pm 0.07^{*}$ & $0.27 \pm 0.06^{*}$ & $1.02 \pm 0.06^{*}$ & $34.54 \pm 0.98$
\end{tabular}

Table 5. The content of MDA, cytochrome C, and catalase and superoxide dismutase activity in the

\begin{tabular}{l|l|l|l|l}
\multirow{2}{*}{ Experimental group } & \multicolumn{4}{|c}{ mitochondria of liver gerbils, $\mathrm{M} \pm \mathrm{SD}, \mathrm{n}=6}$. \\
& $\begin{array}{l}\text { Parameters } \\
\text { MDA, } \mu \mathrm{mol} \mathrm{mg} \mathrm{of} \\
\text { protein }\end{array}$ & $\begin{array}{l}\text { Catalase, } \mu \text { kat per mg } \\
\text { of protein }\end{array}$ & $\begin{array}{l}\text { SOD, c.u. per mg of } \\
\text { protein }\end{array}$ & $\begin{array}{l}\text { Cyt C, nmol per g of } \\
\text { tissue }\end{array}$ \\
\hline \multicolumn{5}{|l|}{ Mitochondria of liver } \\
\hline Control & $6.49 \pm 0.11$ & $11.94 \pm 1.01$ & $7.65 \pm 0.78$ \\
\hline Humilid & $3.75 \pm 0.31$ & $7.37 \pm 0.63^{*}$ & $11.83 \pm 1.29$ & $9.38 \pm 1.09 *$
\end{tabular}

The catalase activity was increased 1.14 times in the mitochondria of the liver of gerbils supplemented with Humilid, but the activity of SOD, in this case, varied within the control group. The concentration of cytochrome $\mathrm{C}$ increased 1.23 times in the mitochondria of liver gerbils only.

The decrease of 2 times the number of MDA was determined in the liver gerbils' mitochondria under Humilid impact compared to the control group (Table 4). Such a decrease of oxidized compounds indicates the potent antioxidant properties of humic substances of the tested humates. The possible modulating antioxidant mechanism that reduces the number of oxidized products in the cell is directly connected with catalase. Catalase is an important oxidoreductase that is a part of the macromolecular antioxidant system at whole [47]. This enzyme's activity was increased in the liver mitochondria under of Humilid effect. The changes of concentration MDA and catalase activity in the liver of gerbils' mitochondria have an inverse correlation $(r=-0.6)$ that indicates the induction of antioxidant system and improvement of the adaptation processes.

Moreover, the standard diet with supplemented 1\% Humilid for chicken-broilers induced the same decrease in oxidized products in the muscle's mitochondria. It increased catalase activity with decreased superoxide activity dismutase compared to the control group.

Thus, increased CT activity as in the liver and muscles in mitochondria is a positive sign of inhibiting processes of the formation of oxidative products and activating adaption under the xenobiotic influence.

The observed decrease of SOD activity in the liver (Table 3) and mitochondria of chicken-broilers muscles (Table 4) under the impact of humic substances may be due to their ability to recombine with intermediate free radicals [26] that may lead to inactivation of enzyme partly.

One more important component of antioxidant protection of the cell from the toxic action of superoxide anion intensively formed in the respiratory chain and SOD is cytochrome $\mathrm{C}$, the highest levels of one are recorded in the liver, and in particular, its mitochondria [5759]. This is a heme-containing protein that required the presence of Ferrum ion in the structure. The oxidized form of cytochrome $\mathrm{C}\left(\mathrm{Fe}^{3+}\right)$ exhibits powerful antioxidant properties at the 
expense of more effectiveness than SOD, the oxidation of superoxide anion to molecular oxygen, and represents a marker of the effectiveness of the antioxidant system of mitochondria.

A simultaneous increase in cytochrome C's concentration in the mitochondria and liver homogenate of gerbils under Humilid impact (Table 3) indicates the intensification of biosynthetic processes. Thus, an increase in cytochrome $\mathrm{C}$ concentration leads to more efficient absorption of oxygen by mitochondria of the liver. As a result, energy supply to cells due to activation of electron transport in the respiratory chain of mitochondria and associated oxidative phosphorylation. The results are supported with data described in Visser's (1987) [46], which demonstrated the enhancement of oxidative phosphorylation of rat liver mitochondria during prolonged exposure to humic substances.

\section{Conclusions}

The diet, supplemented with humic compounds' biologically active additives, led to the activation of the glutathione system of erythrocytes' antioxidant protection. The positive effect of humic feed additives was noted on the liver and muscles' antioxidant system. However, the modulation of the antioxidant system in rodents and poultry liver under the influence of natural humic additives is different.

\section{Funding}

This research received no external funding.

\section{Acknowledgments}

The authors express deep gratitude to the specialist of the Khristyeva Problem Laboratory of Humic Substances, Dnipro State Agrarian, and Economic University.

\section{Conflicts of Interest}

The authors declare no conflicts of interest.

\section{References}

1. Stepchenko, L.M.; Zhorina, L.; Kravtsova, L. The effect of sodium humate on metabolism and resistance in highly productive poultry. Nauchnye doklady vysshě shkoly. Biologicheskie nauki 1991, 10, 90-95.

2. Stepchenko, L.; Galyzina, L. Influence biologically of active feed addition of "Gumilid" is on the meat productivity of the black African ostrich at his industrial growing. News of Dnipropetrovsk State Agrarian and Economic University, 2011, 1, 165-171.

3. Weber, T.E.; van Sambeek, D.M.; Gabler, N.K.; Kerr, B.J.; Moreland, S.; Johal, S.; Edmonds, M.S. Effects of dietary humic and butyric acid on growth performance and response to lipopolysaccharide in young pigs. J. Anim. Sci. 2014, 92, 4172-4179, https://doi.org/10.2527/jas2013-7402.

4. Disetlhe, A.R.P.; Marume, U.; Mlambo, V.; Hugo, A. Effects of dietary humic acid and enzymes on meat quality and fatty acid profiles of broiler chickens fed canola-based diets. Asian-Australas J Anim Sci 2019, 32, 711-720, https://doi.org/10.5713/ajas.18.0408.

5. Semjon, B.; Marcinčáková, D.; Koréneková, B.; Bartkovský, M.; Nagy, J.; Turek, P.; Marcinčák, S. Multiple factorial analysis of physicochemical and organoleptic properties of breast and thigh meat of broilers fed a diet supplemented with humic substances. Poult. Sci. 2020, 99, 1750-1760, https://doi.org/10.1016/j.psj.2019.11.012.

6. Wang, Q.; Ying, J.; Zou, P.; Zhou, Y.; Wang, B.; Yu, D.; Li, W.; Zhan, X. Effects of Dietary Supplementation of Humic Acid Sodium and Zinc Oxide on Growth Performance, Immune Status and Antioxidant Capacity of Weaned Piglets. Animals 2020, 10, 2104, https://doi.org/10.3390/ani10112104. 
7. Ipek, H.; Avci, M.; Iriadam, M.; Kaplan, O.; Denek, N. Effects of humic acid on some hematological parameters, total antioxidant capacity and laying performance in Japanese quails. Archiv fur Geflugelkunde 2008, 72, 56-60.

8. Arafat, R.Y.; Khan, S.H.; Saima. Evaluation of Humic Acid as an Aflatoxin Binder in Broiler Chickens. Annals of Animal Science 2017, 17, 241-255, https://doi.org/10.1515/aoas-2016-0050.

9. Le Guillou, D.; Bucher, S.; Begriche, K.; Hoët, D.; Lombès, A.; Labbe, G.; Fromenty, B. Drug-Induced Alterations of Mitochondrial DNA Homeostasis in Steatotic and Nonsteatotic HepaRG Cells. J. Pharmacol. Exp. Ther. 2018, 365, 711, https://doi.org/10.1124/jpet.117.246751.

10. Arif, M.; Alagawany, M.; Abd El-Hack, M.E.; Saeed, M.; Arain, M.A.; Elnesr, S.S. Humic acid as a feed additive in poultry diets: a review. Iranian journal of veterinary research 2019, 20, 167.

11. Dobrzański, Z.; Chojnacka, K.; Trziszka, T.; Opaliński, S.; Bobak, Ł.; Konkol, D.; Korczyński, M. The Effect of Dietary Humic Preparations on the Content of Essential and Non-Essential Chemical Elements in Hen Eggs. Animals 2020, 10, 1252, https://doi.org/10.3390/ani10081252.

12. Yörük, M.A.; Gül, M.; Hayirli, A.; Macit, M. The Effects of Supplementation of Humate and Probiotic on Egg Production and Quality Parameters During the Late Laying Period in Hens. Poult. Sci. 2004, 83, 84-88, https://doi.org/10.1093/ps/83.1.84.

13. Šamudovská, A.; Demeterová, M. Effect of diet supplemented with natural humic compounds and sodium humate on performance and selected metabolic variables in broiler chickens. Acta Veterinaria Brno 2010, 79, 385-393, https://doi.org/10.2754/avb201079030385.

14. Arafat, R.Y.; Khan, S.H.; Abbas, G.; Iqbal, J. Effect of dietary humic acid via drinking water on the performance and egg quality of commercial layers. American Journal of Biology and Life Sciences 2015, 3, 26-30.

15. Vašková, J.; Krempaská, K.; Žatko, D.; Mudroň, P.; Glinská, G.; Vaško, L. Effects of Humic Acids in Chronic Lead Poisoning. Biol. Trace Elem. Res. 2019, 187, 230-242, https://doi.org/10.1007/s12011-018-1375-1.

16. Stepchenko, L.M.; Loseva, E.O.; Skorik, M.V.; Goncharova O.V. Functional stan for the organisms of productive birds for the development of hydrohumate. News of Dnipropetrovsk State Agrarian and Economic University, 2008, 2, 99-103.

17. Buchko, O.M. Free radical processes in the pig lets for the actions of humic additives. Anim. Biol 2013, 15, 27-33, https://doi.org/10.15407/animbiol15.01.027.

18. Mikhaylenko, E. Haematological and biochemical parameters broiler chickens in the introduction to their rations of biologically active feed additives "Humilid" with water. Scientific and technical bulletin Research Center for Biosafety and Environmental Control of Agricultural Resources 2015, 3(4), 132-135.

19. Myhaylenko, E.O.; Dyomshyna, O.O.; Stepchenko, L.M. Protein and amino acid metabolism in the muscles o f broiler chickens Cobb500 during thearment feed additive «Humilid». Scientific Messenger of LNU of Veterinary Medicin e and Biotechnologies 2017, 19, 110-116, https://doi.org/10.15421/nvlvet7725.

20. Dyomshina, O.O.; Ushakova, G.O.; Stepchenko, L.M. The effect of biologically active feed additives of humilid substances on the antioxidant system in liver mitochondria of gerbils. Regulatory Mechanisms in Biosystems 2017, 8, https://doi.org/10.15421/021729.

21. Prihodchenko, V.O.; Gladka, N.I. Efficiency bioactive feed additive humisol in the diet of broiler chickens. Scientific Messenger of LNU of Veterinary Medicine and Biotechnologies 2013, 15, 3(57), 3, 185-191.

22. Stepchenko, L.M. Significant of cathepsin B and its inhibitors in the regulation of metabolic processes in broiler under the influence of humic substances of nature. The Animal Biology 2010, 12(2), 180-187.

23. Kolyada, S.H. Activity of digestive enzymes of chyme in ostriches by the influence of Humilide, The Animal Biology 2015, 17, 89-95.

24. Rybalka, M.A.; Stepchenko, L.M.; Shuleshko, O.O.; Zhorina, L.V. The impact of humic acid additives on mineral metabolism of rabbits in the postnatal period of ontogenesis. Regulatory Mechanisms in Biosystems 2020, 11, https://doi.org/10.15421/022043.

25. Surai, P.F.; Kochish, I.I.; Fisinin, V.I.; Kidd, M.T. Antioxidant defence systems and oxidative stress in poultry biology: An update. Antioxidants 2019, 8, 235, https://doi.org/10.3390/antiox8070235.

26. Žatko, D.; Vašková, J.; Vaško, L.; Patlevič, P. The effect of humic acid on the content of trace element in Mitochondria. American Journal of Animal and Veterinary Sciences 2014, 9, 315-319, https://doi.org/10.3844/ajavsp.2014.315.319.

27. Paronik, V.A.; Stecchenko, L.M.; Diachenko, L.M.; Levyi, A.E.; Shevtsova, A.I. Influence of corvitine and humidi $\mathrm{d}$ on the state of the oxidative-antioxidant system of rats on th e background of adrenaline introduction. Anim. Biol. 2015, 17, 109-114. 
28. Gunchak, A.; Stepchenko, L.; Ratich, I.; Stefanishin, O. Efficiency of humin-based compounds in quail diet. News of Dnipropetrovsk State Agrarian and Economic University 2017, 2, 53-57.

29. Dziuba, V.O.; Kuchmenko, O.B.; Yakoviichuk, O. V. Status of prooxidative-antioxidative balance and activity of Krebs cycle enzymes in liver, heart and kidney tissues for action of various cumulative doses of doxorubicin. The Animal Biology 2018, 20, 28-39, http://doi.org/10.15407/animbiol20.01.028.

30. Szabó, J.; Vucskits, A.V.; Berta, E.; Andrásofszky, E.; Bersényi, A.; Hullár, I. Effect of fulvic and humic acids on iron and manganese homeostasis in rats. Acta Vet. Hung. 2017, 65, 66-80, https://doi.org/10.1556/004.2017.007.

31. Hullár, I.; Vucskits, A.V.; Berta, E.; Andrásofszky, E.; Bersényi, A.; Szabó, J. Effect of fulvic and humic acids on copper and zinc homeostasis in rats. Acta Vet. Hung. 2018, 66, 40-51, https://doi:10.1556/004.2018.005.

32. Stepchenko, L.M.; Syedykh, N.J. Development of Biocadastre of Ukrainian peats and its use in creating of new humic preparations for agriculture, Peatlands in Balance. Proceedings of the 14 th International Peat Congress, Stockholm, Sweden, June 3-8, 2012, 129-130.

33. Stepchenko, L. M.; Kryvaya, O. A.; Chumak, V.O. Determination of the level of safety of Humilid during biotesting at ciliates. Theor. Appl. Vet. Med. 2019, 7, 210-214, https://doi.org/10.32819/2019.74037.

34. DIRECTIVE 2010/63/EU of the European Parliament and of the Council of 22 September 2010 on the protection of animals used for scientific purposes. Book DIRECTIVE 2010/63/EU of the European Parliament and of the Council of 22 September 2010 on the protection of animals used for scientific purposes. City 2010, 33-78.

35. Law of Ukraine "On Protection of Animals from Cruel Treatment" Vidomosti Verhovnoi Rady Ukrainy Official Bulletin of the Verkhovna Rada of Ukraine 2006, 21 February, 27.

36. Ellman, GL. Tissue sulfhydryl groups. Arch. Biochem. Biophys. 1959, 82, 70-77.

37. Karpishchenko, A.I. Meditsinskie laboratornye tekhnologii i diagnostika: spravochnik [Medical laboratory technologies and diagnostics: reference book]. St. Petersburg: Intermedika 1999.

38. Dominiczak, M.H. Tietz Textbook of Clinical Chemistry. By CA Burtis and ER Ashwood, editors. Clin. Chem. Lab. Med. 1999, 37, 1136-1136.

39. Dillon, W.G.; Glomski, C.A. The Mongolian gerbil: qualitative and quantitative aspects of the cellular blood picture. Lab. Anim. 1975, 9, 283-287, https://doi:10.1258/002367775780957250.

40. Wieckowski, M.R.; Giorgi, C.; Lebiedzinska, M.; Duszynski, J.; Pinton, P. Isolation of mitochondriaassociated membranes and mitochondria from animal tissues and cells. Nat. Protoc. 2009, 4, 1582-1590, https://doi:10.1038/nprot.2009.151.

41. Koroliuk, M.A. A method of determining catalase activity. Lab. Delo 1988, 1, 16-19.

42. Kostiuk, V.A.; Potapovich, A.I. A simple and sensitive method of determination of superoxide dismutase activity based on the reaction of quercetin oxidation. Vopr. Med. Khim. 1990, 36, 88-91.

43. Choi, S.; Swanson, J.M. Interaction of cytochrome c with cardiolipin: an infrared spectroscopic study. Biophys. Chem. 1995, 54, 271-278, https://doi.org/10.1016/0301-4622(94)00151-9.

44. Andreeva, L.I.; Kozhemiakin, L.A.; Kishkun, A.A. Modification of the method of determining lipid peroxidation in a test using thiobarbituric acid. Lab. Delo 1988, 41-43.

45. van Rensburg, C.E.J. The Antiinflammatory Properties of Humic Substances: A Mini Review. Phytother. Res. 2015, 29, 791-795, https://doi.org/10.1002/ptr.5319.

46. Visser, S.A. Effect of humic substances on mitochondrial respiration and oxidative phosphorylation. Sci. Total Environ. 1987, 62, 347-354.

47. Gülden, M.; Jess, A.; Kammann, J.; Maser, E.; Seibert, H. Cytotoxic potency of H2O2 in cell cultures: Impact of cell concentration and exposure time. Free Radical Biol. Med. 2010, 49, 1298-1305, https://doi.org/10.1016/j.freeradbiomed.2010.07.015.

48. Robert, A.M.; Robert, L. Xanthine Oxido-Reductase, Free Radicals and Cardiovascular Disease. A Critical Review. Pathology \& Oncology Research 2014, 20, 1-10, https://doi.org/10.1007/s12253-013-9698-X.

49. Thingale, A.D.; Shaikh, K.S.; Channekar, P.R.; Galgatte, U.C.; Chaudhari, P.D.; Bothiraja, C. Enhanced hepatoprotective activity of andrographolide complexed with a biomaterial. Drug Deliv. 2015, 22, 117-124, https://doi.org/10.3109/10717544.2013.871602.

50. McGarry, T.; Biniecka, M.; Veale, D.J.; Fearon, U. Hypoxia, oxidative stress and inflammation. Free Radical Biol. Med. 2018, 125, 15-24, https://doi.org/10.1016/j.freeradbiomed.2018.03.042.

51. Kim, S.H.; Kim, H. Inhibitory Effect of Astaxanthin on Oxidative Stress-Induced Mitochondrial DysfunctionA Mini-Review. Nutrients 2018, 10, https://doi.org/10.3390/nu10091137. 
52. Abrahams, S.; Haylett, W.L.; Johnson, G.; Carr, J.A.; Bardien, S. Antioxidant effects of curcumin in models of neurodegeneration, aging, oxidative and nitrosative stress: A review. Neuroscience 2019, 406, 1-21, https://doi.org/10.1016/j.neuroscience.2019.02.020.

53. Swat, M.; Rybicka, I.; Gliszczyńska-Świgło, A. Characterization of Fulvic Acid Beverages by Mineral Profile and Antioxidant Capacity. Foods 2019, 8, https://doi.org/10.3390/foods8120605.

54. Sentman, M.-L.; Granström, M.; Jakobson, H.; Reaume, A.; Basu, S.; Marklund, S.L. Phenotypes of mice lacking extracellular superoxide dismutase and copper-and zinc-containing superoxide dismutase. J. Biol. Chem. 2006, 281, 6904-6909, https://doi.org/10.1074/jbc.M510764200.

55. Domínguez-Negrete, A.; Gómez-Rosales, S.; Angeles, M.D.; López-Hernández, L.H.; Reis-de Souza, T.C.; López-García, Y.; Zavala-Franco, A.; Téllez-Isaias, G. Effect of the Addition of Humic Substances as Growth Promoter in Broiler Chickens Under Two Feeding Regimens. Animals 2019, 9 , https://doi.org/10.3390/ani9121101.

56. Serova, D.; Taran, O.; Dyomshina, O. Biological activity of humic substances in the liver of Mongolian gerbils (Meriones unguiculatus). Biosystems Diversity 2016, 24, 410-415, https://doi.org/10.15421/011655.

57. Hüttemann, M.; Pecina, P.; Rainbolt, M.; Sanderson, T.H.; Kagan, V.E.; Samavati, L.; Doan, J.W.; Lee, I. The multiple functions of cytochrome $\mathrm{c}$ and their regulation in life and death decisions of the mammalian cell: From respiration to apoptosis. Mitochondrion 2011, 11, 369-381, https://doi.org/10.1016/j.mito.2011.01.010.

58. Li, D.; Li, L.; Li, P.; Li, Y.; Chen, X. Apoptosis of HeLa cells induced by a new targeting photosensitizerbased PDT via a mitochondrial pathway and ER stress. Onco Targets Ther. 2015, 8, 703, https://doi.org/10.2147/OTT.S76370.

59. Kalpage, H.A.; Bazylianska, V.; Recanati, M.A.; Fite, A.; Liu, J.; Wan, J.; Mantena, N.; Malek, M.H.; Podgorski, I.; Heath, E.I.; Vaishnav, A.; Edwards, B.F.; Grossman, L.I.; Sanderson, T.H.; Lee, I.; Huttemann, M. Tissue-specific regulation of cytochrome c by post-translational modifications: respiration, the mitochondrial membrane potential, ROS, and apoptosis. The FASEB Journal 2019, 33, 1540-1553, https://doi.org/10.1096/fj.201801417R. 